\title{
LIF wt Allele
}

National Cancer Institute

\section{Source}

National Cancer Institute. LIF wt Allele. NCI Thesaurus. Code C50952.

Human LIF wild-type allele is located in the vicinity of $22 q 12.2$ and is approximately $6 \mathrm{~kb}$ in length. This allele, which encodes leukemia inhibitory factor protein, plays a role in the differentiation of both macrophages and astrocytes. 